\title{
INTEGRASI KARAKTER HAMBA TUHAN KE DALAM PELAYANAN DALAM BINGKAI TEOLOGI MATHEUS MANGENTANG
}

\author{
Malik \\ Sekolah Tinggi Teologi Injili Arastamar (SETIA) Jakarta \\ malikbambangan@sttsetia.ac.id
}

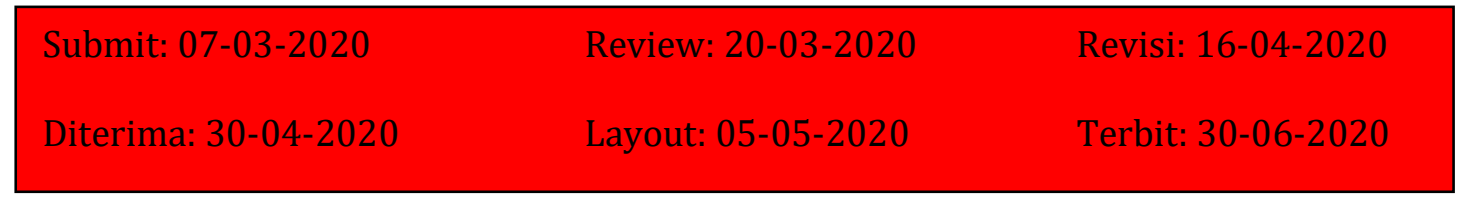

\begin{abstract}
The determinant of success in one's service is sustained by good and true character. Various attempts were made by educational institutions to implement character building in the learning process. But how can success in service if they do not have good character like Christ's character? The purpose of this study is to reduce the teaching of the theology of Matheus Mangentang about the character of God's servants in ministry at Sekolah Tinggi Teologi Injili Arastamar (hereinafter abbreviated SETIA) Jakarta and Gereja Kristen Setia Indonesia (hereinafter abbreviated as GKSI). The method used is an interview with Matheus Mangentang as the primary source of data and collecting data on centralization relating to the discussion of this topic. As a result, the character of God's servants in the theology of Matheus Mangentang is still relevant and can be integrated in the service of God's servants in SETIA and GKSI. The conclusion of this study is that the character of God's servants in the framework of the theology of Matheus Mangentang is very much needed in carrying out special services in SETIA and GKSI.
\end{abstract}

Keywords: God; Character; Servant; Service; SETIA; GKSI; Matheus; Mangentang

\begin{abstract}
Abstrak
Penentu keberhasilan dalam pelayanan seseorang adalah ditopang oleh karakter yang baik dan benar. Berbagai upaya yang dilakukan lembaga pendidikan untuk menerapkan pembentukan karakter dalam proses pembelajaran. Namun bagaimana bisa berhasil dalam pelayanan jika tidak memiliki karakter yang baik seperti karakter Kristus? Tujuan penelitian ini adalah untuk mereduksi ulang pengajaran teologi Matheus Mangentang tentang karakter hamba Tuhan dalam pelayanan di Sekolah Tinggi Teologi Injili Arastamar (selanjutnya disingkat SETIA) Jakarta dan Gereja Kristen Setia Indonesia (selanjutnya disingkat GKSI). Adapun metode yang digunakan adalah wawancara dengan Matheus Mangentang sebagai sumber primer data serta mengumpulkan datadata kepusatkaan yang berkaitan dengan pembahasan topik ini. Sebagai hasil bahwa karakter hamba Tuhan dalam teologi Matheus Mangentang masih relevan dan dapat diintegrasikan dalam pelayanan hamba Tuhan di SETIA dan GKSI. Kesimpulan dari penelitian ini adalah karakter hamba Tuhan dalam bingkai teologi Matheus Mangentang sangat diperlukan dalam melaksanakan pelayanan secara khusus di SETIA dan GKSI.
\end{abstract}

Kata Kunci: Tuhan; Karakter; Hamba; Pelayanan; SETIA; GKSI; Matheus; Mangentang 


\section{Pendahuluan}

Sikap hidup seseorang sangat ditentukan dari bagaimana ia berbuat sesuatu dalam kehidupannya, baik kepada orang lain, maupun kepada diri sendiri. Ijinkan saya mengutip sebuah pepatah dalam Bahasa Jawa kuno; "Ajining Diri Gumantung Obahing Lati" harga diri seseorang tergantung dari apa yang ucapkan dan ('lakukan'-pen'). Apa yang membawa seseorang pada suatu puncak kesuksesan tersebut adalah tergantung dari apa yang lakukan. Namun tidak sedikit orang yang mengalami kegagalan untuk sampai pada tahap puncak tersebut. Berbicara mengenai perilaku seseorang adalah menyangkut tentang karakter. Esther Rela Intarti menuliskan, membentuk karakter bukanlah pekerjaan yang hanya dilakukan dalam sekejap mata dengan memberikan nasihat, perintah atau instruksi, namun lebih dari hal itu. Pembentukan karakter memerlukan teladan atau Role model, kesabaran, pembiasaan dan pengulangan. ${ }^{1}$ Selain kesabaran dan keteladanan dalam menanamkan karakter, juga sangat perlu suatu pembiasaan. Artinya karakter ini sangat perlu dibudayakan dalam segala lini kehidupan. Budaya karakter yang baik begitu dirindukan oleh semua pihak agar tatanan kehidupan sosial masyarakat ini berjalan sebagaimana mestinya.

Ketika Indonesia mengalami perubahan ekonomi dan sistem birokrasi, banyak 'aparatur negara' yang mengalami goncangan karena terindikasi oleh korupsi. Hal ini juga menuai reaksi yang pro dan kontra dari berbagai kalangan masyarakat terhadap kebijakan pemerintah dalam membasmi budaya korup bagi para pejabatnya. Ada yang setuju dengan tindakan pemerintah dalam memberantas tindakan korupsi, namun ada juga yang tidak setuju. Diantara kedua kelompok manusia ini ada juga kelompok poros tengah, yakni mereka yang tidak mau ikut campur dalam persoalan tersebut, namun katanya mereka juga memiliki prinsip yaitu siapa menang itu yang mereka ikuti. Kelompok poros tengah sudah memposisikan diri mereka sebagai orang yang tidak memiliki prinsip dan karakter yang baik. Mengapa demikian? Karena mereka tidak memiliki sikap tegas untuk berkata ya dan tidak dalam mengambil keputusan. Dengan demikian dapat disimpulkan bahwa tindakan koruptor tersebuat berkaitan erat dengan karakter manusia. Yang menjadi pertanyaan adalah, apakah para koruptor tersebut memiliki karakter atau tidak? Jika meraka memiliki karakter, lalu apakah karakter mereka setuju untuk melakukan Tindakan korupsi yang sama dengan mencuri uang negeri tersebut? Tentu saja karakter ini sudah melampaui batas, namun tidak bagi mereka yang sudah bobrok akhlak dan karakternya. Karakter mereka tidak tahan uji ketika diperhadapkan dengan masalah yang besar dan berat. Begitu cepatnya hati nurani mereka berubah hanya karena godaan harta benda.

Berbicara tentang karakater dalam kehidupan para hamba Tuhan, apakah hal ini juga memegang peran penting dalam pelayanan? Bagaimanakah pembahasan tentang karakter dalam kalangan hamba Tuhan yang ada dalam kalangan SETIA dan GKSI selama 33 tahun ini? Apakah hamba Tuhan masih mengedepankan sikap, watak dan karakter yang benar dalam pelayanannya atau sudah mengalami kemunduran oleh karena terpaan badai dan goncangan dunia? Masihkah alumni SETIA mengerjakan misi yang dipelajari selama studi atau sudah berubah arah dan tujuan? Intarti menyatakan bahwa, Pendidikan karakter adalah Pendidikan untuk mengubah karakter atau kebiasaan yang buruk dalam diri seseorang atau Pendidikan untuk membentuk watak atau tabiat atau kebiasaan yang baik dalam diri seseorang. ${ }^{2}$ Inilah yang menjadi dasar peneliti mengangkat topik ini agar semua hamba Tuhan SETIA dan GKSI kembali kepada

1 Esther Rela Intarti, Jurnal MIDRASH Vol.3 Nomor 2. ISSN: 9772302797001-Pembentukan Karakter Berbasis Nilai-Nilai Kristiani Bagi Peserta Didik Melalui Peran Guru Pendidikan Agama Kristen, (Purwokerto: STT Diakonos, 2017), 131

${ }^{2}$ Intarti, Jurnal MIDRASH Vol.III Nomor 2. ISSN: 9772302797001,131 
Visi dan Misi awal panggilannya. Ketetapan pada melaksanakan Visi dan Misi SETIA adalah merupakan suatu prinsip, dan orang yang memiliki prinsip adalah orang yang berkarakter baik adanya. Dalam buku Visi dan Misi SETIA, Matheus Mangentang dengan sangat lugas dan gamblang membahas persoalan karakter hamba Tuhan, secara khusus mahasiswa SETIA, alumni SETIA, Dosen \& Staf SETIA serta para hamba Tuhan GKSI. Artikel ini dibuat sebagai wujud apresiasi yang tinggi kepada Lembaga SETIA Jakarta dibawah pimpinan ketua Dr. Dyulius Thomas Bilo, M.Th. yang boleh memasuki usia 33 tahun dalam dunia pelayanan dan tetap exis serta berekesinambungan.

\section{Metode Penelitian}

Adapun penggunaan metode dalam penelitian ini adalah dengan melakukan wawancara kepada sumber primer serta mengumpulkan data-data Pustaka yang berkaitan dengan topik ini dipadukan dengan pengamatan peneliti dilapangan kemudian menyusunnya menjadi sebuah tulisan (artikel).

\section{Hasil Dan Pembahasan}

Menurut Kamus Besar Bahasa Indonesia (KBBI) sebagaimana dikutip oleh Intarti, kata karakter dapat diartikan tabiat, sifat-sifat kejiwaan, akhlak atau budi pekerti yang membedakan seseorang dengan yang lain, atau dapat juga diartikan watak. $^{3}$ Berdasarkan definisi ini, dapat dimaknai bahwa karakter adalah suatu sifat atau tabiat yang memiliki perbedaan dengan orang lain. Dan orang yang berkarakter tersebut akan selalu tampil beda dari yang lainnya. Secara terminologis Thomas Lickona yang dikutip oleh Marzuki dalam Suyadi mendefinisikan karakter sebagai, a reliable inner disposition to respond to situations in a moraly good way. ${ }^{4}$ Selanjutnya Intarti menjelaskan bahwa,

Karakter mengacu pada kebiasaan berpikir, berperasaan, bersikap, berbuat, membentuk tekstur dan motivasi kehidupan seseorang. Karakter erat dengan pola tingkah laku, kecenderungan pribadi untuk berbuat baik. Karakter sebagai sesuatu yang melekat pada personal yaitu totalitas ide, aspirasi, sikap yang terdapat dalam individu dan telah mengkristal pada pikiran dan tindakan. ${ }^{5}$

Karakter adalah kualitas atau kekuatan mental atau moral, akhlak atau budi pekerti individu merupakan kepribadian khusus yang menjadi pendorong dan penggerak, serta yang membedakannya dengan individu yang lain. Pengembangan kepemimpinan terjadi melalui perkembangan karakter, karena kepemimpinan adalah masalah karakter. ${ }^{6}$ Pembentukan karakter dapat merupakan proses yang lambat, dan kadang-kadang menyakitkan. Tetapi orang yang mau membiarkan Allah menyelesaikan proses itu akan mengenal sukacita karena dipakai Allah. Dua faktor menentukan lamanya waktu yang diperlukan Allah untuk membentuk karakter yang layak sebagai pemimpin rohani, yakni; kepercayaan kepada Allah dan ketaatan kepada Allah. ${ }^{7}$ Kepercayaan kepada Allah adalah merupakan kunci utama dalam pelayanan. Mengambil komitmen untuk melayani Tuhan adalah suatu gerakan iman yang mempercayai Allah sepenuhnya pada setiap lini kehidupannya. Untuk mewujudkan

\footnotetext{
3 Intarti, Jurnal MIDRASH Vol.III Nomor 2. ISSN: 9772302797001, 131

4 Suyadi, Strategi Pembelajaran Pendidikan Karakter, (Bandung: Rosda Karya, 2015), 5

5 Intarti, Jurnal MIDRASH Vol.III Nomor 2. ISSN: 9772302797001, 132

${ }^{6}$ Henry \&Richard Blackaby, Kepemimpinan Rohani, (Batam: GOSPEL PRESS, 2005), 82

${ }^{7}$ Blackaby, Kepemimpinan Rohani, 83
} 
iman kepercayaan tersebut, maka dalam hal ini dibutuhkan yang namanya ketaatan. Ketaatan untuk melakukan apa yang dipercaya kepada Allah adalah suatu pengakuan iman dan kesetiaan. Sebagai hamba Tuhan mestinya memiliki hal tersebut agar dapat menopang dan menunjang pelayanannya. Dengan demikian karakter dapat terbentuk baik dari dalam, maupun dari luar. Pembentukan dari luar adalah melalui masalah yang dihadapi oleh seseorang akan dapat membentuknya menjadi pribadi-pribadi yang Tangguh dan kokoh tatkala dia mengambil keputusan untuk melaluinya. Demikian juga dengan pembentukan dari dalam adalah suatu sikap yang terbentuk melalui masalah yang dihadapi akan membentuk seseorang menjadi pribadi-pribadi yang memiliki iman dengan bersandar dan bergantung sepenuhnya pada TUHAN. Berkaitan dengan pembentukan karakter dapat dibentuk juga melalui pendidikan karakter. Doni Koesoema A. menuliskan, karena pendidikan karakter terkait dengan pembentukan diri manusia, definisi dan pemahamannya mesti selaras dan konsisten dengan pemahaman antropologis yang mendasarinya. ${ }^{8}$ Itu artinya karakter ini sangat diperlukan dalam hidup manusia untuk bermasyarakat. Kehidupan manusia tidak hanya ditopang dari individu (dari dalam), namun perlu juga ditopang dari luar (lingkungan sosial). Koesoema menuliskan, bahwa melalui panggilan pribadi dalam dunia, manusia menanggapi pertumbuhannya sebagai individu, sekaligus sebagai pelaku perubahan tatanan dalam masyarakatnya. ${ }^{9}$

\section{Tujuan Pembentukan Karakter}

\section{A. Takut akan Tuhan}

Salah satu tujuan Allah menciptakan manusia adalah untuk menjadi kawan sekerja Allah di muka bumi ini. Oleh sebab itu sebagai hamba Tuhan, hendaknya memiliki rasa takut dan hormat kepada Allah. Rasa takut akan Allah ini hendaknya didefinisikan sebagai suatu sikap hormat atau penghormatan, penghargaan kepada Allah. Hidup takut kepada Allah adalah hidup yang senantiasa memuliakan Allah yang ditandai dengan ketaatan dan kesetiaan dalam melakukan firman Tuhan itu sendiri. Sejatinya sikap atau karakter yang takut akan Tuhan akan terbentuk dari iman yang kokoh dengan berpegang teguh pada kebenaran yang hakiki tanpa ragu dan bimbang. Itulah sebabnya panggilan mengenai karakter takut akan Tuhan ini merupakan panggilan umum atau universal bagi seluruh umat manusia dan secara khusus bagi para hamba Tuhan, meskipun masih ada orang yang dengan sengaja mengabaikannya.

Sikap hidup yang menghormati Allah adalah suatu karakter ilahi manusia yang percaya kepada-Nya. Dengan demikian mereka terpanggil untuk bersikap dan bertingkah laku sesuai dengan panggilannya masing-masing.

\section{B. Hidup secara Benar di Hadapan Tuhan}

Untuk membutkikan suatu pola hidup yang benar di hadapan Tuhan tentu memiliki kriteria apa yang perlukan untuk mewujudkan karakter seperti ini. Hal ini akan tercermin dari sikap hidup kudus dan tak bercelah di hadapan Tuhan dan sesama. Inilah karakter yang hidupnya benar di hadapan Tuhan. Karakter seorang hamba Tuhan akan termanifestasi dalam hidup kudusnya. 'Panggilan untuk hidup kudus, tidak hanya

\footnotetext{
${ }^{8}$ Doni Koesoema A, Pendidikan Karakter, (Yogyakarta: Penerbit Kanisius, 2012),53

${ }_{9}^{9}$ Doni Koesoema A, Pendidikan Karakter, 66
} 
ditujukan pada kalangan orang Kristen tertentu saja, namun di setiap kalangan orang yang sudah ditebus menjadi milik Yesus.'10

\section{Rendah hati}

Kerendahan hati seseorang terkadang dijadikan senjata orang lain untuk menindasnya dengan semena-mena. Karakter yang rendah hati tidak selamanya selalu memberi diri untuk ditindas dengan semena-mena, namun ada kalanya untuk bangkit dan menyatakan sikap. Les Carter dalam bukunya yang berjudul Pembentukan Karakter, menulis bahwa Yesus sangat memahami jika kapan waktunya untuk menyatakan pendapat-Nya baik dengan tegas atau lemah lembut. Selanjutnya Carter menulis bahwa ada saatnya dimana harus diam dan tidak perlu menanggapi suatu masalah yang timbul. ${ }^{11}$ Karakter yang rendah hati adalah suatu sikap yang lahir dari hati dan kepribadian seseorang melalui tingkah lakunya setiap saat. Rendah hati tidak boleh ditafsirkan secara hurufiah yang artinya orang yang selalu tunduk dan hormat kepada orang lain, namun hal ini lebih mengarah kepada suatu keberadaan seseorang di dalam memanajemen hatinya, tutur katanya serta tindakannya. Kerendahan hati seseorang dapat diukur melalui bagaimana seseorang dalam mengendalikan dirinya. Bagaimana ia mampu menguasai lidahnya dalam berkata-kata sehingga selalu memuliakan Allah Bapa di Sorga (Yak. Kemampuan untuk mengontrol tingkah lakunya dalam hidup bergaul dengan sesama.

\section{Kasih}

Karakter yang baik akan mampu membentuk moralitas hidup manusia untuk mampu mengasihi baik kepada Tuhan maupun kepada sesama manusia dalam segala aspek kehidupannya. Definisi kasih yang sering dilupakan adalah kata 'memberi.' Tujuan pembentukan karakter akan menjadikan manusia hidup dalam kasih, baik itu melalui pikiran, perasaan maupun kehendaknya. Karakter yang terbentuk dalam wadah kasih, menjadikannya sebagai pribadi yang selalu memberi kepada Tuhan dan sesama manusia. Yesus mengajarkan kepada murid untuk hidup dalam kasih antara satu dengan yang lain (Yoh. 15:17). Namun kasih haruslah sungguh-sungguh dengan melibatkan seluruh aspek hidup manusia. Yesus berkata; Kasihilah Tuhan Allahmu dengan segenap hatimu dan dengan segenap jiwamu dan dengan segenap akal budimu. Itulah hukum yang terutama dan yang pertama. Dan hukum yang kedua yang sama dengan itu, ialah: kasihilah sesamamu manusia seperti dirimu sendiri (Mat. 37:39). Jadi Yesus mengajarkan kepada para murid untuk mengasihi Tuhan dan sesama dengan segenap hati, jiwa dan akal budi. Hal ini mencakup tentang karakter manusia secara khusus sebagai hamba Tuhan agar dalam pelayanannya ia mampu menerapkan kasih itu secara total.

\section{E. Kesetiaan}

Kesetiaan berbicara tentang ketahanan, keteguhan untuk mencapai tujuan, khusunya Ketika berada dalam bahaya dan bencana. ${ }^{12}$ Selanjutnya kesetiaan adalah kasih yang sanggup bertahan pada segala sesuatu-kesulitan, bahaya dan perbedaan-

10 J. Knox Chamblin, Paulus dan Diri- Ajaran Rasuli bagi Keutuhan Pribadi, (Surabaya: Penerbit Momentum, 2006), 172

${ }^{11}$ Les Carter, Pembentukan Karakter, (Bandung: Lembaga Literatur Baptis , 2011), 236

${ }^{12}$ John M. Drescher, Melakukan Buah Roh, (Jakarta: BPK GM, 2011), 208 
perbedaan. ${ }^{13}$ Kemampuan untuk memilah setiap perbedaam dalam pelayanan dan menyelesaikannya dengan baik adalah membutuhkan suatu sikap yang taat dan setia. Untuk membuktikan kesetiaan seseorang dapat bertahan dan berlaku di masyarakat, maka diperlukan karakter yang baik dan matang. Di sini berbicara tentang kehidupan manusia secara menyeluruh. Doni Koesoema A. menuliskan, Pendidikan karakter yang utuh dan menyeluruh melengkapi dimensi keterpanggilan manusia dalam sejarah sebagai pelaku bagi perubahan dirinya dan masyarakat. ${ }^{14}$ Pelayanan yang maksimal dan diperkenan Tuhan adalah pelayanan yang memiliki jiwa setia dalam pelayanannya. Kesetiaan seseorang akan menentukan sampai kapan ia mampu bertahan dalam pelayanannya.

\title{
F. Penguasaan diri
}

Topik ini adalah suatu bagian dari buah roh dalam Galatia 5:23, namun secara tidak sadar juga kadang-kadang buah roh yang kesembilan ini menjadi penentu semua karakter manusia. Betapa tidak, jika seseorang memiliki karakter yang sangat baik, namun ia tidak bisa menguasai dirinya, maka semua itu akan buyar. Pentingnya penguasaan diri dalam segala hal akan menuntun seseorang menjadi arif dan bijaksana dalam mengambil setiap keputusan. Drescher menulis, Para moralis selalu menempatkan pentingnya penguasaan diri tetapi mereka tidak menyadari betapa dalam dan agungnya hal itu dalam konsep kekristenan. ${ }^{15}$ Rasul Petrus menuliskan juga tentang hal ini, kesudahan segala sesuatu sudah dekat. Karena itu kuasailah dirimu dan jadilah tenang, supaya kamu dapat berdoa (1Ptr.4:7). Orang yang mampu menguasai dirinya akan menjadi tenang tanpa tergopoh-gopoh dalam bertindak. Dan pada akhirnya orang yang menguasai dirinya menurut rasul Petrus akan dapat berdoa. Apakah yang membuat seseorang itu tidak dapat menguasai dirinya? Karena mereka masih diperbudak oleh hawa nafsu dan keinginan daging. Drescher menjelaskan, Roh Kudus memberikan kepada manusia keinginan dan kekuatan untuk mengontrol nafsu, dorongan hati, imajinasi dan berbagai macam keinginan lainnya. ${ }^{16}$ Ada beberapa hal yang perlu diketahui dalam hal penguasaan diri sebagai pengikat karakter seseorang.

Pertama, penguasaan diri berarti menahan diri dari apa yang diketahui salah. ${ }^{17}$ Beberapa hamba Tuhan masih bergumul pada pokok ini bahkan ada yang berkata ini dilematis. Bermain-main dengan apa yang sudah diketahui salah, sama halnya dengan mendukakan Roh Kudus Tuhan yang sudah mendiami diri orang percaya. Begitu juga dengan Yakobus yang menuliskan. Jadi jika seorang tahu bagaimana ia harus berbuat baik, tetapi ia tidak melakukannya, ia berdosa (Yak.4:17). Kedua, penguasaan diri lebih dari sekedar menjaga diri dari keinginan jahat dan nafsu. Penguasaan diri membantu bagaimana seseorang mengorbankan yang lebih kecil untuk mencapai yang lebih tinggi, bagaimana membedakan antara yang baik dan yang terbaik. ${ }^{18}$ Ketiga, penguasaan diri mencakup tentang kedisiplinan seseorang dalam melakukan tugas dan tanggungjawabanya. ${ }^{19}$

\section{Integrasi Karakter Hamba Tuhan Dalam Bingkai Teologi Matheus Mangentang}

\author{
13 Drescher, Melakukan Buah Roh, 208 \\ 14 Doni Koesoema A, Pendidikan Karakter, 64 \\ 15 Drescher, Melakukan Buah Roh, 260 \\ 16 Drescher, Melakukan Buah Roh, 261 \\ 17 Drescher, Melakukan Buah Roh, 261 \\ 18 Drescher, Melakukan Buah Roh, 262 \\ ${ }^{19}$ Drescher, Melakukan Buah Roh, 263
}


Berbicara mengenai karakter adalah berbicara tentang tingkah laku seseorang dalam hal bagaimana ia berbuat. Hal ini juga dapat kita bicarakan sebagai suatu hal yang berkaitan erat. Dimana kepemimpinan hamba Tuhan haruslah memiliki karakter yang benar di hadapan Tuhan. Karakter ini ditunjang juga oleh adanya spiritualitas seorang pemimpin Kristen sehingga akan berdampak positif kepada orang lain. Demikian juga dengan factor penunjang karakter yang lain yakni; moralitas yang baik, kredibilitas, integritas yang tinggi, serta responsibility. ${ }^{20}$ Kecenderungan perilaku yang tidak bertanggung jawab akan berakibat fatal dalam pelayanan seseorang. Pada puncaknya diakhiri dengan kegagalan. Mengapa gagal? Karena ia tidak mengerti visi dan misi yang ia kerjakan seperti apa dan bagaimana, sehingga ia tidak tahu harus berbuat apa Ketika masalah datang menerpanya. Hal inilah sangat dibutuhkan karakter yang kuat dan Tangguh sehingga ia dapat tetap hidup dan bertahan di tengah suasana yang tidak menguntungkan sekalipun. Oleh sebab itu penugasan Allah selalu didasarkan pada karakter, makin besar karakternya, makin besar pula penugasannya. ${ }^{21}$

Memasuki 33 tahun SETIA Jakarta tepatnya 11 Mei 2020 adalah suatu momen dimana gerakan misi Allah Kembali lagi dikobarkan dalam pelayanan. Meskipun ditengah masa pandemic covid-19, ini kiranya tidak menghalangi para hamba Tuhan untuk terus menyalakan pelita Injil bagi jiwa-jiwa yang hidup dalam kegelapan. Hal ini tidaklah menyurutkan semangat dan antusiasme daripada civitas akademika SETIA Jakarta serta para alumni untuk kembali menggelorakan jiwa dan semangat untuk terus bermisi. Lalu bagaimana mengintegrasikan karakter tersebut dalam pelayanan agar tetap survive serta terus berkembang? Berikut ini hal-hal yang perlu diperhatikan sebagai hamba Tuhan berkaitan dengan karakter yang melayani Tuhan sebagai integrasi dalam pelayanan.

\section{A. Karakter Pendoa}

Salah satu kunci keberhasilan hamba Tuhan dalam kehidupan dan pelayanannya adalah memiliki karakter sebagai pendoa. Doa merupakan komunikasi dua arah manusia dengan Allah. Kehidupan doa seorang hamba Tuhan akan menjadikannya tetap ada di hadirat Allah yang Agung dan Sang Pengasih. Kehidupan doa mesti terus dibangun dalam mezbah keluarga, maupun secara pribadi. Inilah sejatinya seorang hamba Tuhan yang memiliki karakter pendoa. ${ }^{22}$ Hal ini tentu membutuhkan kedisiplinan yang kuat dalam diri seseorang untuk melakukannya. Malik Bambangan menyatakan bahwa, Disiplin dalam berdoa atau berkomunikasi dengan Tuhan adalah suatu wujud keakraban orang Kristen sebagai anak dengan Tuhan sebagai Bapa. Berdoa dapat memberi petunjuk kepada setiap orang Kristen untuk melakukan kehendak Tuhan sebagaimana tertulis dalam Firman-Nya. ${ }^{23}$ Inilah life style hamba Tuhan SETIA dan GKSI dari sejak awal mendirikan Lembaga ini sehingga karakter pendoa ini dimasukkan dalam kurikulum Visi dan Misi SETIA oleh Matheus Mangentang.

Blackaby menuturkan, Kebenaran sejati dari hidup ini adalah bahwa hidup ini dipenuhi dengan situasi yang hanya dapat dikalahkan oleh kuasa Allah. Posisi yang

20 Beberapa poin ini saya bahas dalam tulisan saya dengan judul Estfaet Kepemimpinan Kristen dalam Bingkai Teologi Paulus kepada Timotius.

${ }^{21}$ Henry \&Richard Blackaby, Kepemimpinan Rohani, (Batam: GOSPEL PRESS, 2005), 84

22 Matius Mangentang, Visi dan Misi SETIA, (Jakarta: SETIA, 2006),18

${ }^{23}$ Malik Bambangan, Disiplin Rohani -Diktat, (Purwokerto: STT Diakonos, 2016), 30 
paling penuh kuasa yang dapat diambil seorang pemimpin adalah Ketika dia berdoa. ${ }^{24}$ Mengapa sebagai hamba Tuhan harus berdoa? Paparan Blackaby berikut ini mungkin seringkali dilupakan oleh beberapa kalangan hamba Tuhan, karena mereka merasa aman dan nyaman sebagai hamba Tuhan; "Doa adalah kegiatan pemimpin yang penting sekali, doa membawa kepenuhan kuasa Roh Kudus, doa membawa hukmat Allah, doa menggapai kuasa Allah, doa menghilangkan stress, doa menyingkapkan agenda Allah." 25 Sedangkan menurut John Piper, Doa adalah merupakan Tindakan pengejaran akan kemuliaan Allah. ${ }^{26}$ Melalui karakter Pendoa ini diharapakan agar para hamba Tuhan SETIA dan GKSI mampu mengontrol pola hidup agar tetap selaras dengan maksud dan kehendak Tuhan baginya. Kehidupan seorang hamba Tuhan adalah doa karena doa adalah nafas hidup orang percaya. Hal ini senada dengan apa yang dituliskan oleh John Piper bahwa doa adalah merupakan saraf pusat persekutuan dengan Yesus. ${ }^{27}$ Dengan demikian jika hamba Tuhan SETIA dan GKSI tidak berdoa, maka itu artinya mereka tidak bernafas dan beroisah dari persekutuan dengan Yesus.

Dari keenam pilar doa menurut Blackaby tersebut, poin manakah yang sudah Anda lakukan? Apakah ada evaluasi dari jawaban doa tersebut? Hal yang berikut adalah, poin manakah yang belum dilaksanakan? Apakah ada alasan yang logis sehingga tidak melakukannya atau tidak mengalami hal tersebut?

Inti dari doa adalah persekutuan dengan Sumber transformasi di mana kehadiran Tuhan mampu mengubah sebuah keadaan menjadi tidak membosankan. Tidak mungkin terjadi suatu gerakan doa sejati tanpa adanya komunikasi yang hidup dengan Sumber transformasi. Dialah yang mengakibatkan seseorang atau umat Allah dapat berdoa. ${ }^{28}$

\section{1) Penyembahan}

Allah berhak atas pujian sekalipun Allah tidak memerlukan pujian, tetapi manusia lah yang perlu memuji Tuhan. Pujian merupakan sebuah kesaksian iman terhadap kuasa-Nya yang tidak terbatas, bahkan sekalipun ketika lingkungan dan suasana menjadi sangat sulit karena di bawah penganiayaan. Manusia adalah metodenya Tuhan. Gereja mencari metode-metode yang lebih baik. Tuhan mencari orang-orang yang lebih baik. Apa yang gereja butuhkan hari ini bukan mesin-mesin yang lebih baik, bukan organisasi yang baru atau metode novel yang modern, tetapi orang-orang yang dapat dipakai oleh Roh Kudus. Kemudian orang-orang yang berdoa, orang-orang yang perkasa dalam doa. Roh Kudus tidak turun atas mesin tetapi atas orang-orang percaya. Ia tidak mengurapi rencana-rencana, tetapi manusia yakni orang-orang percaya yang berdoa. ${ }^{29}$

\section{2) Ucapan Syukur}

Rasul Paulus menuliskan dalam 1 Timotius 2:1 demikian, "Pertama-tama aku menasihatkan: Naikkanlah permohonan, doa syafaat dan ucapan syukur untuk semua orang." Ucapan syukur dalam doa adalah perwujudan sepakat dengan Tuhan atas semua yang sudah dan akan terjadi dan ini merupakan rahasia kehadiran Tuhan dan juga sekaligus jawaban atas doa yang dinaikkan yang mengakibatkan terobosan intervensi ilahi yang melahirkan transformasi baru.

3) Pengakuan

\footnotetext{
24 Blackaby, Kepemimpinan Rohani, 210

25 Blackaby, Kepemimpinan Rohani, 214

26 John Piper, Mendambakan Allah, (Surabaya: Penerbit Momentum, 2008), 172

27 John Piper, Mendambakan Allah, 190

28 Eddy Leo, Transformasi Indonesia (Jakarta: Metanoia 2003) hal.90

29 Tim Shofar, This is That (Jakarta: Media Transformation) hal 212
} 
Merupakan unsur penting lainnya dari doa secara khusus pengakuan dosa. Ketika memasuki hadirat Allah Yang Maha Kudus melalui doa, setiap orang percaya harus mengizinkan Roh Kudus untuk menyadarkan akan segala perkara yang tidak menyenangkan Allah dan segera mengakuinya, serta merasa yakin bahwa Dia akan mengampuni. Pengakuan harus bersifat spesifik dan mencakup suatu kemauan untuk melakukan pemulihan yang dipimpin oleh Tuhan. Lukas 18:13 menuliskan demikian: "Tetapi pemungut cukai itu berdiri jauh-jauh, bahkan ia tidak berani menengadah ke langit, melainkan ia memukul diri dan berkata:Ya Allah, kasihanilah aku orang berdosa ini." Tuhan selalu melihat dan menilai hati seseorang saat datang pada-Nya, sehingga tidak ada satupun yang dapat disembunyikan di hadapan-Nya. Penampilan luar bisa menipu, tetapi Tuhan tidak mungkin dapat ditipu, jadi segala sesuatu yang kelihatan dari luar tidaklah menjamin sebuah doa dikabulkan.

\section{4) Permohonan}

Dalam berdoa adalah penting dipahami bahwa terdapat juga permohonan kepada Allah. Namun yang perlu dipahami di sini adalah apakah permohonan itu sudah sesuai dengan kehendak Allah Bapa atau hanya karena kehendak si pendoa saja? Memang tidak dapat dipungkiri bahwa berdoa adalah suatu bukti ketergantungan manusia kepada Allah dan salah satunya adalah dengan memohon perlindungan-Nya. Akan tetapi permohonan dalam doa pada hakekatnya adalah permohonan untuk kepentingan pekerjaan Allah dan orang lain setelah itu memohon untuk kepentingan pribadi.

Berdasarkan paparan di atas, mengindikasikan suatu pertanyaan kepada orang percaya bahwa apakah orang percaya sudah melakukan bentuk permohoanan ini dalam setiap doanya? MacDonald menyatakan demikian,

Seringkali saya berdoa dengan memikirkan hasil. Saya ingin mendapatkan kendali atas orang dan kejadian yang saya doakan dengan mendikte pandangan saya kepada Bapa tentang bagaimana segala sesuatu harus terjadi. Bila saya melakukan hal itu, saya memandang pada orang dan kejadian melalui lensa bumi ini dan bukan dengan lensa surgawi. Saya berdoa seolah saya lebih tahu daripada Allah akan apa hasil yang terbaik seharusnya. ${ }^{30}$

Inilah kunci yang membuka semua istana keputusasaan dan juga membuka gudang harta Tuhan. Kesederhanaan doa seorang anak yang meminta kepada Bapanya, yang memberi dengan kebesaran hati, penuh kebebasan, dan dengan sukacita, di atas semua orang tua yang ada di dunia. ${ }^{31}$ Dalam tiga kata, yaitu minta, cari, dan ketuk terletak pemberian Kristus bagi orang percaya. Ialah yang memerintahkan dan menjanjikan dengan cara yang paling kuat. Hal ini menunjukkan bahwa jika orang percaya bertekun dalam doa berarti dia naik ke tingkat yang lebih tinggi dan lebih kuat, dan menyelam ke kedalaman yang lebih pekat dan usaha yang lebih keras, jawabannya pasti akan datang.

\section{B. Karakter Pejuang}

Upaya perwujudan hasil dari suatu usaha seseorang adalah ditentukan dari proses perjuangannya dalam mewujudkan apa yang diinginkan. Bagi Matheus Mangentang selalu menganjurkan agar setiap hamba Tuhan SETIA dan GKSI memiliki karakter

30 Gordon MacDonald, Menata Dunia Pribadi, Meniti Sukses Sejati, (Jakarta: Waskita Publishing, 2012),187

${ }^{31}$ Tim Shofar, This is That, (Jakarta: Media Transformation), 210-211 
sebagai seorang pejuang. ${ }^{32}$ Setiap pelayanan hendaknya dibarengi dengan usaha semaksimal mungkin, karena tanpa usaha yang maksimal, maka hasilnya tidak akan maksimal juga. Oleh sebab itu sangat dibutuhkan karakter pejuang sebagai hamba Tuhan dalam menjalankan pelayanannya. Tidak sedikit hamba Tuhan yang memiliki sikap malas dalam pelayanan, sehingga pelayanannya tidak berkembang dan menjadi staqnan dan pada akhirnya pos pelayanannya menjadi tutup karena tidak ada perkembangan, malahan yang terjadi adalah anggota jemaatnya menjadi berkurang. Oleh sebab itu para hamba Tuhan hendaknya jangan lari dari pelayanan Ketika mendapatkan masalah apapun, melainkan tetaplah ditempatmu dengan setia sambil menanti pertolongan TUHAN. Blackbaby menyatakan bahwa, kejadian-kejadian di luar kendali seseorang dapat punya dampak yang sama seperti halnya kegagalan.

Kejadian itu dapat menghancurkan seorang calon pemimpin atau kejadian itu akan membentuk karakter dan keteguhan di dalam calon pemimpin itu yang memampukan dia mencapai posisi yang lebih tinggi di masa depan. ${ }^{33}$ Allah membentuk karakter melalui pengalaman dan krisis kehidupan sehari-hari. Sebagian besar pembentukan karakter tidak terjadi Ketika seseorang menghadiri seminar atau mengambil kursus. Sebaliknya, Allah memakai kejadian sehari-hari, yang baik maupun yang buruk, untuk membentuk pemimpin. ${ }^{34}$ Mayoritas hamba Tuhan secara khusus alumni SETIA kaget setengah mati ketika diperhadapakan dengan situasi lapangan pelayanan. Ternyata apa yang di dalam pikirin mereka tidak sesuai dengan kenyataan. Hal ini mengakibatkan mereka mengambil keputusan sendiri untuk meninggalkan tempat pelayanan dan akibatnya pos pelayanan tersebut mengalami kekosogan hamba Tuhan. Karakter yang lemah seperti ini tidak dapat dipakai dalam pelayanan di SETIA dan GKSI.

Oleh sebab itu Matheus Mangentang mengajarkan ini kepada setiap mahasiswa agar memiliki karakter sebagai seorang pejuang. Karakter ini memiliki makna bahwa seluruh hamba Tuhan adalah orang yang mau berusaha dan pantang mundur. Karakter hamba Tuhan yang dapat memanfaatkan peluang untuk dapat melayani Tuhan meskipun dalam situasi yang sulit sekalipun.

\section{Karakter Pekerja}

Menjadi pemimpin tidak berarti orang itu sudah mencapai suatu taraf tertentu sehingga tidak perlu lagi bekerja keras. Sebaliknya para pemimpin harus menetapkan derap langkah untuk orang-orang lain dalam organisasi itu. Tidak ada yang lebih membuat pegawai dan sukarelawan berkecil hati dibandingkan pemimpin yang malas. Para pemimpin tidak boleh meminta pengikutnya mengerjakan tugas yang mereka sendiri tidak mau kerjakan. ${ }^{35}$ Model hamba Tuhan yang malas bekerja dengan hanya memerintah orang lain (anggota jemaat), tanpa ia sendiri tidak mengerjakannya sebagai contoh, cenderung bermasalah dalam pelayanan. Balckaby menjelaskan bahwa, Yesus mengajar murid-murid-Nya bukan hanya dengan kata-kata saja, tetapi melalui keteladan-Nya. Bahkan Ketika murid-murid Yesus dianiaya, mereka tahu Yesus telah memberi mereka teladan penderitaan (Mat. 10:24-25). ${ }^{36}$ Itu artinya bahwa sebagai hamba Tuhan mestinya memiliki hati pemimpin yang mau memberi teladan. Hamba Tuhan memiliki karakter seorang pekerja ${ }^{37}$ bukan pemalas.

\footnotetext{
32 Mangentang, Visi dan Misi SETIA, 19

33 Blackaby, Kepemimpinan Rohani, (Batam:GOSPEL PRESS, 2005

34 Blackaby, Kepemimpinan Rohani, 84

35 Blackaby, Kepemimpinan Rohani, 214-215

36 Blackaby, Kepemimpinan Rohani, 215

37 Mangentang, Visi dan Misi SETIA, 18
} 
Matheus Mangentang sangat menghidupi karakter-karakter yang diajarkan kepada para mahasiswa dan ditanamkan dalam sikap hidup para hamba Tuhan dalam pelayanan. Dalam hal ini penulis sendiri mengamati bahwa apa yang diajarkan oleh Matheus Mangentang itu sudah diterapkan dalam hidup pelayanannya sehingga dapat diterapkan dalam pengajarannya. Mengapa harus bekerja? Karena ini adalah ajaran Tuhan Yesus kepada para murid-Nya, Tetapi Ia berkata kepada mereka: : Bapa-Ku bekerja sampai sekarang, maka Akupun bekerja juga."(Yoh. 5:17). Demikian juga Paulus menasehatkan kepada jemaat di Tesalonika agar orang yang tidak mau bekerja, janganlah ia diberi makan. "Sebab, juga waktu kami berada di antara kamu, kami memberi peringatan ini kepada kamu: jika seorang tidak mau bekerja, janganlah ia makan (2 Tes. 3:10)." Matheus Mangentang selalu memberikan pengarahan secara khusus kepada para hamba Tuhan dalam setiap moment Ketika beliau pelayanan ke daerah-daerah dengan mengadakan seminar/pembinaan, KKR mengatakan: "jika masih ada orang bisa hidup dan bertahan di daerah atau kampung dimana engkau ditugaskan melayani, maka seharusnya engkaupun juga harus bisa hidup dan bertahan di sana sama seperti mereka." Pernyataan ini yang seringkali disalah mengerti oleh beberapa alumni SETIA yang pelayanan di GKSI dengan bergumam bahwa, "kita disuruh pergi untuk mati", padahal ini adalah suatu tantangan sekaligus penghiburan bahwa masakan orang di sana bisa hidup, kalian tidak bisa hidup?

Karakter pekerja bukanlah semata-mata bertujuan agar hamba Tuhan itu bisa bekerlimpahan harta, namun yang paling penting bahwa pekerjaan adalah suatu rutinitas manusia selagi masih hidup. Dengan bekerja keras akan menghasilakan suatu berkat dari usaha sendiri dan menjadi teladan bagi jemaat serta masyarakat pada umumnya. Demikian juga dengan pelayanannya akan selalu berjalan baik dan lancer dari sisi ekonominya. Apakah ini merupakan gaya hidup materialistis? Tidak juga, karena dalam pelayanan dapat ditopang oleh keberadaan materi. Sebagaimana pelayanan Yesus juga ditopang oleh perempuan-perempuan yang kaya yang sekaligus menjadi murid Yesus selain dari yang dua belas orang. ${ }^{38}$ Bekerja selain untuk memenuhi kebutuhan hidup dan pelayanan, juga dapat dipergunakan untuk menolong sesame manusia. Dengan adanya berkat yang lebih sebagai hasil dari pekerjaan seorang hamba Tuhan, dapat membagi berkat orang lain, secara khusus bagi anggota jemaat. Walaupun demikian tidak diharapkan bahwa jemaat selalu mengharapkan bantuan dari gembala sidangnya, karena hukumnya adalah bahwa anggota jemaatlah yang mestinya menopang pelayanan gembala sidang, sehingga hamba Tuhan tersebut fokus untuk anggota jemaatnya, dan bukannya sibuk untuk mengurusi pekerjaan rumah tangganya sendiri. Beberapa kasus terjadi di pelayanan, bahwa banyak alumni SETIA yang tidak bisa bertahan di pelayanan karena, salah satu faktor penyebabnya adalah kemalasan untuk bekerja. Kemalasan ini menjadi batu sandungan bagi anggota jemaat serta masyarakat sekitar. ${ }^{39}$

\section{Karakter Pemberani}

Kesetiaan dalam Bahasa Yunani berasal dari kata pistis yang memiliki asal kata Iman. Itu artinya bahwa orang yang setia memiliki keberanian untuk tetap bertahan dalam segala keadaan sampai genap waktunya untuk berhenti melakukannya. Pelayanan membutuhkan suatu karakter pemberani yang dapat diartikan sebagai suatu sikap yang gigih dan tidak mudah menyerah dalam menghadapi berbagai macam

38 Malik Bambangan, Mengelola Harta Kekayaan, (Yogyakarta: Penerbit ANDI, 2013), 94

39 Hasil Pengamatan Penulis selama pelayanan sebagai Ketua Sektor, 2004-2010 dalam jajaran Gereja Kristen Setia Indonesia (GKSI) lokus Sulawesi Selatan (Ketua Sektor Seriti) dan Sulawesi Barat (Ketua Badan Pengurus Wilayah GKSI). 
tantangan. Pemberani bukan berarti diarahkan kepada orang lain, namu pemberani lebih mengarah kepada sikap sejati seorang hamba Tuhan yang tidak gampang ditakuttakuti. Sehingga pelayan tersebut lari dari pelayanan.

Saya menghadapi banyak tantangan dalam pelayanan baik itu Ketika membuka pos PI GKSI yang baru, maupun dalam pelayanan di jemaat. Tantang yang datang bukan hanya dari luar, namun juga dari dalam. Syukur kepada Tuhan bahwa keluarga dekat saya termasuk kedua orangtua mayoritas sudah menjadi anggota GKSI. Nah tantang dari dalam ini sendiri dari jemaat yang pura-pura bergabung untuk menghancurkan pelayanan ini dari dalam. Namun dengan iman selalu saya tegaskan bahwa jika memang benar Tuhan memakai SETIA dan GKSI serta memakai saya dalam pelayanan ini, maka biarlah pelayanan ini berakhir dalam Tangan Tuhan, bukan dalam tangan manusia. Banyak juga kesaksian pelayanan para hamba Tuhan yang mengalami hambatan, ada yang disidang, ada yang dilempari batu dan diusir, namun semua itu tidak membuat takut serta kecut dan tawar hati sehingga lari dari panggilan pelayanan. Justru dengan peristiwa-peristiwa tersebut akan memotivasi dalam pelayanan agar terus waspada dan maju. Matheus Mangentang selalu memberikan pengajaran bahwa pelayanan yang berkembang dan dipimpin oleh Tuhan adalah pelayanan yang mengalami tantangan namun akhirnya menang, dengan prinsip, tanpa tantangan, tidak ada kemajuan (no pain, no gain). Istilah ini sudah saya dengar dengan telinga sendiri dari bapak Matheus Mangentang sejak tahun 2004 sampai sekarangpun masih tetap dikumandangkan. Meskipun hal ini menimbulkan multitafsir, karena ada yang mengatakan bahwa kalau banyak tantangan berarti perlu koreksi, akan tetapi kelemahan pendapat ini akan menjadi senjata iblis untuk meruntuhkan semangat pelayanan sebagai endingnya pelayan akan mempersalahkan diri dan akhirnya putus asa. Tentu hal ini tidak boleh terjadi dalam pelayanan SETIA dan GKSI.

Keberanian hamba Tuhan dalam pelayanan akan teruji jika ia berhasil membawa Injil Kristus ke daerah terpencil dan memenangkan daerah tersebut bagi Kristus. Dia tidak gampang menyerah dan putus asa, apalagi gagal dalam pelayanan. Memang tidak sedikit hamba Tuhan yang meninggalkan tempat pelayanan karena takut ketika mendapat ancaman, ketika tidak mendapat suplai kebutuhan pokok. Ada juga yang meniggalkan tempat pelayanan karena tidak tahan hidup di desa yang tidak ada jaringan komunikasi, tidak ada masa depan. Namun kondisi ini tidak menajdikan pelayanan menjadi mundur, justru dengan kondisi ini dijadikan bahan evaluasi agar mempersiapkan dan mengutus hamba-hamba Tuhan yang siap menantang zaman.

Karakter pemberani yang alkitabiah adalah sama seperti Yesus yang dengan tegas mengusir para pedagang dan penukar uang dalam halaman Bait Allah (Mrk.11:15-16). Ketegasan Yesus ini menurut Veldhuis, tidak terletak pada Tindakan penuh kekerasan. ${ }^{40}$ Selanjutnya Henri Veldhuis menyatakan bahwa, radikalitas sejati Yesus terletak dalam penerjemahan dan penerapan kitab suci dan tradisi Yahudi. ${ }^{41}$ Itu artinya bahwa Yesus memiliki kepekaan rohani yang mendalam karena cinta-Nya akan rumah Allah. Siapakah bait Allah saat ini? Paulus dengan tegas berkata, tidak tahukah kamu bahwa kamu adalah bait Allah dan bahwa Roh Allah diam di dalam kamu? (1Kor. 3:16). Demikian jugalah para hamba Tuhan hendaknya berani menegor apa yang salah, menyatakan apa yang benar. Dalam hal ini sangat dibutuhkan kepekaan seorang hamba Tuhan dalam menjalankan tugas pelayanannya. Jika seorang hamba Tuhan tidak lagi memiliki kepekaan dalam pelayanan, maka tunggulah bahwa pelayanannya akan segera berakhir.

40 Henri Veldhuis, Kutahu yang Kupercaya, (Jakarta: BPK Gunung Mulia, 2010), 132

41 Veldhuis, Kutahu yang Kupercaya, 132 
Karakter pemberani adalah suatu tindakan radikalis para murid Kristus dalam memberitakan Injil. Yesus memberikan perintah kepada para murid dalam memberitakan Injil-Nya agar tidak takut dan gentar. Yesus berkata, 'Dan janganlah kamu takut kepada mereka yang dapat membunuh tubuh, tetapi yang tidak berkuasa membunuh jiwa; takutlah terutama kepada Dia yang berkuasa membinasakan baik jiwa maupun tubuh di dalam neraka' (Mat.10:28; Luk.12:4). Para murid Kristus masa kini yakni gereja memiliki tugas dan tanggung jawab untuk menjalankan pemberitaan Injil Kristus (Mat.28:19; Mrk. 16:15; Luk.24:47; Yoh. 20:21-23). Zoschak menjelaskan, 'Yesus tidak hanya memperingatkan pengikut-pengikut-Nya tentang roh ketakutan yang akan menyerang, Yesus menjelaskan agar mereka berani menumbuhkan kasih Bapa yang sempurna dala diri mereka. ${ }^{42}$ Dalam memberitakan Injil Kristus memang banyak tantangan, namun yakinlah bahwa janji Tuhan untuk menyertai para murid termasuk hamba Tuhan SETIA dan GKSI adalah ya dan amin. Penyertaan-Nya adalah sampai kesudahan alam bahkan sampai selama-lamanya (Mat. 28:20; Mrk.16:17-20; Luk.24:49; Yoh.14:18, 16:7). Jadi tidak ada alasan untuk takut dalam pelayanan kecuali Anda berbuat kesalahan, maka resiko ditanggung sendiri jangan bawa-bawa nama Lembaga, pimpinan, apalagi nama Tuhan.

Tindakan tegas seorang hamba Tuhan adalah suatu karakter yang harus terus ditumbuhkembangkan dalam pelayanan. Ketegasan dalam pelayanan tidaklah dapat disamakan dengan tindakan kekerasan. Meskipun banyak jemaat menilai jika ada hamba Tuhan yang tegas itu sama dengan kekerasan. Oleh sebab itu karakter pemberani di sini bukan juga diartikan sebagai tindakan brutal yang melawan tatanan hukum yang berlaku di atas nilai-nilai kemanusiaan, namun lebih mengarah kepada Tindakan revolusi mental demi kemajuan pelayanan di lading-Nya Tuhan. Tindakan tegas hamba Tuhan adalah suatu karakter hamba Tuhan yang berani dan disiplin serta jujur untuk berkata tidak kepada dosa. Paulus menasehati Timotius agar tetap konsisten dalam pelayanannya, Beritakanlah firman, siap sedialah baik atau tidak baik waktunya, nyatakanlah apa yang salah, tegorlah dan nasihatilah dengan segala kesabaran dan pengajaran (2 Tim. 4:2). Jadi pemberani yang dimaksudkan adalah sebuah Tindakan tegas dalam melaksanakan pelayanan yang tentunya dengan kasih. Sebagaimana Paulus dalam menasihati Timotius, 'janganlah engkau keras terhadap orang yang tua, melainkan tegorlah dia sebagai bapa. Tegorlah orang-orang muda sebagai saudaramu (1Tim.5:1). Jadi karakter pemberani yang dimaksudkan dalam tulisan ini seperti yang diajarkan oleh Matheus Mangentang adalah tidak bertentangan dengan Alkitab karena keberanian yang dimaksudkan adalah berani memberitakan Injil, berani atau tegas dalam pelayanan tanpa kompromi dengan dosa. Oleh sebab itu, sebagai hamba Tuhan SETIA dan GKSI adalah pemberani dalam mengambil tindakan untuk kemajuan pekerjaan Tuhan.

\section{E. Karakter Kreatif 43}

Kreativitas dalam pelayanan sangat dibutuhkan untuk mengurai tingkat kejenuhan. Seseorang bisa merasa tidak nyaman atau tidak berkembang karena merasa jenuh dengan rutinitas yang ia lakukan setiap hari. Tuntutan bagi kemajuan suatu pelayanan seorang hamba Tuhan adalah bagaimana ia memiliki kreativitas dalam pelayanannya. Mahasiswa dan hamba Tuhan SETIA telah diperlengkapi dengan ilmu teologi, pengajaran (Pendidikan), ilmu berkhotbah dan berbagai keterampilan yang

42 Greg Zoschak, Membangun Karakter Anda, (Jakarta: Immanuel, 2003), 25

43 Mangentang, Visi dan Misi SETIA, 19 
INTEGRASI KARAKTER HAMBA TUHAN KE DALAM ... (Malik)

sekarang disebut dengan entrepreneurship. Penulis mengembangankan pokok ini dengan menambahkan bahwa sebagai bukti hamba Tuhan yang kreatif, maka dituntut untuk mampu melakukan pelayanan dengan kreatif, inovatif, edukatif, aplikatif dan efektif. Jika beberapa 'tif (penulis) ini, dilakukan dengan konsisten dan berkesinambungan, maka niscaya tidak berhasil. Sebagai hamba Tuhan yang meskipun berada di pedusunan yang jauh dari keramaian kota serta fasilitas yang tidak mendukung, namun tidak perlu kehilangan ide atau cara untuk melakukan pelayanan. Begitu banyak orang yang mengaku dirinya hamba Tuhan, namun pelayanannya menjadi kering dan tidak terdapat perkembangan atau kemajuan dalam pelayanannya, bahkan ada sampai menjadi bubar dikarenakan tidak mampu mengelola pelayanan tersebut dengan maksimal. Banyak juga pelayanan yang mengalami mati suri karena pelayannya tidak memiliki ide-ide yang kreatif dalam melayani. Karakter kreatif sangat dibutuhkan dalam pelayanan untuk mengelola pelayanan sehingga terjadi pertumbuhan yang signifikan. Sebagai hamba Tuhan perlu kreatif dalam memimpin pujian, menyampaikan Firman Tuhan, mengadakan pastoral konseling, serta pelayanan penginjilan.

\section{Kesimpulan}

Integrasi Karakter dalam pelayanan para hamba Tuhan SETIA dan GKSI adalah suatu kurikulum pelayanan yang sudah ada dalam setiap pribadi pada saat mengambil komitmen bergabung dalam Lembaga SETIA dan GKSI. Hal ini merupakan barometer pelayanan dimana seorang hamba Tuhan hendaknya tetap memiliki dan menjaga agar karakter mereka tetap menjadi berkat bagi semua orang dalam pelayanan. Jika karakter ini terus dilakukan maka pelayanan para hamba Tuhan SETIA dan GKSI akan membawa jiwa bagi kemuliaan Kristus. Demikian juga dengan pencapaian Visi dan Misi agung Tuhan Yesus dalam SETIA dan GKSI akan terealisasi dengan benar.

\section{Referensi}

Bambangan, Malik, Disiplin Rohani -Diktat, (Purwokerto: STT Diakonos, 2016) 
, Mengelola Harta Kekayaan, (Yogyakarta: Penerbit ANDI, 2013)

Blackaby, Richard \& Henry, Kepemimpinan Rohani, (Batam: GOSPEL PRESS, 2005)

Carter, Les, Pembentukan Karakter, (Bandung: Lembaga Literatur Baptis , 2011)

Chamblin, J. Knox, Paulus dan Diri- Ajaran Rasuli bagi Keutuhan Pribadi, (Surabaya: Penerbit Momentum, 2006)

Drescher, John M., Melakukan Buah Roh, (Jakarta: BPK GM, 2011)

Intarti, Esther Rela, Jurnal MIDRASH Vol.3 Nomor 2. ISSN: 9772302797001-Pembentukan Karakter Berbasis Nilai-Nilai Kristiani Bagi Peserta Didik Melalui Peran Guru Pendidikan Agama Kristen, (Purwokerto: STT Diakonos, 2017)

Koesoema A., Doni, Pendidikan Karakter, (Yogyakarta: Penerbit Kanisius, 2012)

Leo, Eddy, Transformasi Indonesia (Jakarta: Metanoia 2003)

MacDonal, Gordon, Menata Dunia Pribadi, Meniti Sukses Sejati, (Jakarta: Waskita Publishing, 2012)

Mangentang, Matius, Visi dan Misi SETIA, (Jakarta: SETIA, 2006)

Piper, John, Mendambakan Allah, (Surabaya: Penerbit Momentum, 2008)

Suyadi, Strategi Pembelajaran Pendidikan Karakter, (Bandung: Rosda Karya, 2015)

Tim Shofar, This is That (Jakarta: Media Transformation)

Veldhuis, Henri, Kutahu yang Kupercaya, (Jakarta: BPK Gunung Mulia, 2010)

Zoschak, Greg, Membangun Karakter Anda, (Jakarta: Immanuel, 2003) 